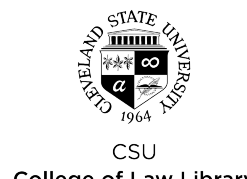

Cleveland State University

College of Law Library

\title{
EngagedScholarship@CSU
}

2007

\section{Privatizing Public Forums to Eliminate Dissent}

Kevin F. O'Neill

Cleveland State University, k.oneill@csuohio.edu

Follow this and additional works at: https://engagedscholarship.csuohio.edu/fac_articles

Part of the First Amendment Commons

How does access to this work benefit you? Let us know!

Original Citation

Kevin F. O'Neill, Privatizing Public Forums to Eliminate Dissent, 5 First Amendment Law Review 201 (2007)

This Article is brought to you for free and open access by the Faculty Scholarship at EngagedScholarship@CSU. It has been accepted for inclusion in Law Faculty Articles and Essays by an authorized administrator of EngagedScholarship@CSU. For more information, please contact research.services@law.csuohio.edu. 


\section{HEINONLINE}

Citation: 5 First Amend. L. Rev. 201 2006-2007

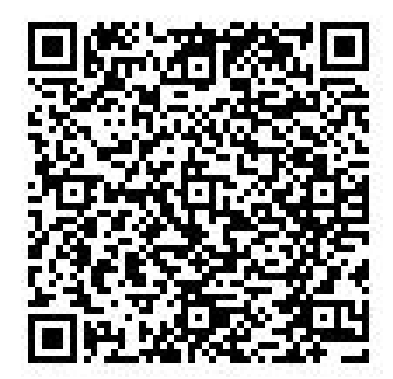

Content downloaded/printed from

HeinOnline (http://heinonline.org)

Wed Dec 4 20:39:06 2013

-- Your use of this HeinOnline PDF indicates your acceptance of HeinOnline's Terms and Conditions of the license agreement available at http://heinonline.org/HOL/License

-- The search text of this PDF is generated from uncorrected OCR text. 


\title{
PRIVATIZING PUBLIC FORUMS TO ELIMINATE DISSENT
}

\author{
KEVIN FRANCIS O'NEILL*
}

\section{INTRODUCTION}

As the 2008 presidential campaign gets underway, the candidates may be tempted to suppress dissent at public forum rallies by using a tactic that Ronald Reagan pioneered ${ }^{2}$ and George W. Bush perfected. ${ }^{3}$ Under this tactic, the candidate's advance team "privatizes" a public square or public park by securing a municipal permit for the rally date that authorizes the expulsion of any citizen who manifests support for a rival candidate. ${ }^{4}$ At a 2004 Bush re-election rally, citizens who held signs opposing the President or opposing the war in Iraq were systematically expelled from a public park by Secret Service agents, who asserted that the Republican Party "owned" the park for the day. ${ }^{5}$ Two citizens who questioned their expulsion were arrested for criminal trespass, handcuffed, jailed, and strip-searched. ${ }^{6}$

This tactic for eliminating public forum dissent has generated only a handful of reported cases ${ }^{7}$ and it has never been successfully challenged. My thesis is that, under the First Amendment, neither the

* Associate Professor of Law, Cleveland-Marshall College of Law, Cleveland State University. In writing this article, I received invaluable help from research assistants Katsiaryna Vyhouskaya, Maureen Kenny, Deneen LaMonica, and Malvi Pandya, and generous financial support from the Cleveland-Marshall Fund.

1. See, e.g., Patrick Healy \& Jeff Zeleny, Clinton Enters '08 Field, Fueling Race for Money, N.Y. TIMES, Jan. 21, 2007, at A1; Jeff Zeleny, Obama Starts Bid, Reshaping Democratic Field, N.Y. TIMES, Jan. 17, 2007, at A1.

2. See infra note 55 and accompanying text.

3. See infra note 54 , notes $58-67$, and accompanying text.

4. See infra notes 43-46 and accompanying text.

5. McCabe v. Basham, 450 F. Supp. 2d 916, 920 (N.D. Iowa 2006).

6. $I d$.

7. See infra note 43 and accompanying text. 
government nor its permittee may effect the viewpoint-based expulsion of citizens from a traditional public forum. If a presidential campaign wants to stage an appearance where every member of the audience has been screened to ensure unanimous support for the candidate, then the event should be held on private property, where the First Amendment does not apply. ${ }^{8}$

This article proceeds as follows. In Part I, I sketch the larger First Amendment context in which this tactic should be viewed. It is a context that features two overarching trends: (1) the increasing obsolescence of traditional public forums as a meaningful platform for citizen speech; and (2) the broad range of governmental efforts to eliminate or privatize our traditional public forums. In Part II, I describe in detail how presidential campaigns have employed this tactic and I examine the key cases in which it has been challenged. Finally, in Part III, I offer my own analysis of the tactic's constitutionality.

\section{BIG-PICTURE CONTEXT: THE INCREASING OBSOLESCENCE AND ELIMINATION OF OUR TRADITIONAL PUBLIC FORUMS}

The First Amendment provides vigorous protection for public protest-so long as the protester takes up position in a traditional public forum. ${ }^{9}$ But the list of traditional public forums is a short one. It is

8. Speech restrictions imposed by private actors pertaining to private property are beyond the reach of the First Amendment. Lloyd Corp. v. Tanner, 407 U.S. 551, 567-68 (1972).

9. See, e.g., United States v. Grace, 461 U.S. 171 (1983) (holding that the sidewalks around the United States Supreme Court building constitute a traditional public forum and striking down a statutory prohibition against leafleting or displaying signs on those sidewalks). As one scholar has observed: "[U]nless a traditional public forum is involved, a majority of U.S. Supreme Court Justices can easily manipulate the Court's forum classification principles to enable governments to exclude any private speaker or any type of private expressive activity from government property." Gary D. Allison, Prelude to a Church-State: The Supremes Set the Stage for Faith-Based Initiatives, 37 TULSA L. REV. 111, 138 (2001) (alteration added) (emphasis added). Accord G. Sidney Buchanan, The Case of the Vanishing Public Forum, 1991 U. ILL. L. REV. 949, 952, 956 (1991) (noting the sharp decline in speech protection that attends any shift from a traditional to a designated public forum); Steven G. Gey, Reopening the Public Forum-From Sidewalks to Cyberspace, 58 OHIO ST. L.J. 1535, 1536 (1998) (outside the realm of 
essentially confined to public parks, squares, streets, and sidewalks. ${ }^{10}$ When given the opportunity to expand that list, the Supreme Court has consistently refused."

Now, at the dawn of a new century, our traditional public forums are threatened by two different trends. First, they face increasing obsolescence as a platform for reaching one's fellow citizens. ${ }^{12}$ Fifty years ago, taking up position on a public square would have been an ideal way to gather signatures or pass out leaflets. But today, our traditional public forums are less and less the crossroads of the community, less and less the setting where we encounter our fellow citizens on foot. ${ }^{13}$ For most Americans, the scene of our daily activity

public parks and sidewalks, the Supreme Court is much less protective of expressive freedom).

10. See Cornelius v. NAACP Legal Def. \& Educ. Fund, Inc., 473 U.S. 788, 802 (1985); Hague v. CIO, 307 U.S. 496, 515-16 (1939). See also United States v. Kokinda, 497 U.S. 720,727 (1990) (stressing that traditional public forums are narrowly conceived).

11. See, e.g., Int'l Soc'y for Krishna Consciousness, Inc. v. Lee, 505 U.S. 672, 678-79 (1992) (holding that the public concourses in airport terminals are non-public forums, even though they possess many of the same characteristics as public sidewalks).

12. See Gey, supra note 9, at 1539 (asserting that the importance of parks and sidewalks as venues for serious discussion of public issues "faded long ago"); Matthew D. McGill, Unleashing the Limited Public Forum: A Modest Revision to a Dysfunctional Doctrine, 52 STAN. L. REV. 929, 951 (2000) ("In our modern information age, streets and parks have become less relevant, if not altogether irrelevant, as sites for public debate or distribution and acquisition of information."). See generally VARIATIONS ON A THEME PARK: THE New AMERICAN CITY AND THE END OF PUblic SPACE (Michael Sorkin ed., 1992) (tracing the increasing privatization of "public" space-in the form of shopping malls, sports facilities, entertainment complexes, and gated communities-and the corresponding decline of public squares and sidewalks as the scene of human interaction).

13. See KenNeth T. JaCkson, Crabgrass Frontier: The Suburbanization OF THE UNITED STATES 281 (1985) ("Streets are no longer places to promenade and to meet, but passageways for high-powered machines."); Trevor Boddy, Underground and Overhead: Building the Analogous City, in VARIATIONS ON A THEME PARK, supra note 12 , at 123, 124-25 (recognizing the diminishing significance of public streets as a place of human interaction and a platform for political protest); Rob Kling, Spencer Olin \& Mark Poster, The Emergence of Postsuburbia: An Introduction, in POSTSUBURBAN CALIFORNIA: THE TRANSFormation of ORANGe COUNTY Since WORLD War II 1, 7 (Rob.Kling, Spencer Olin \& Mark Poster eds., 1991) (the spatial layout of postsuburban 
has shifted from publicly-owned to privately-owned spaces, ${ }^{14}$ like shopping malls, ${ }^{15}$ where the First Amendment does not apply. ${ }^{16}$

communities "is designed to accommodate the automobile driver," discouraging the pedestrian use of public sidewalks); Michael Southworth \& Peter M. Owens, The Evolving Metropolis: Studies of Community, Neighborhood, and Street Form at the Urban Edge, J. AM. PlanNING Ass'N, June 22, 1993, at 289 (identifying trends in urban design that "preclude the possibility of a pedestrian-oriented environment"). In the words of James Howard Kunstler:

The extreme separation and dispersion of components that [formerly comprised] a compact town, where everything was within a ten-minute walk, has left us with a public realm that is composed mainly of roads. And the only way to be in that public realm is to be in a car, often alone. The present arrangement has certainly done away with sacred places, places of casual public assembly, and places of repose. Otherwise, there remain only the shopping plazas, the supermarkets, and the malls.

JAMES Howard KunStLER, THE GEOGRAPHY OF NOWHERE: THE RISE AND DECLINE OF AMERICA'S MAN-MADE LANDSCAPE 118-19 (1993) (alteration added). Public squares and sidewalks no longer provide a meaningful opportunity to communicate, face to face, with our fellow citizens. Instead, they serve merely as helpless vantage points from which to view our fellow citizens as they roar past us in sport utility vehicles at 60 miles per hour. The futility of using these traditional public forums as a platform for communication has prompted one author to ask: "Where, then, are you going to have your public assembly? On the median strip of Interstate 87?" Id. at 120 .

As Matthew D. McGill has observed, supra note 12 at 951-52, Justice Kennedy took note of this trend in arguing for an expansive conception of traditional public forums. See Int'l Soc'y for Krishna Consciousness, Inc. v. Lee, 505 U.S. 672, $697-$ 98 (Kennedy, J., concurring) (observing that we now live "in times of fast-changing technology and increasing insularity" and live "in a country where most citizens travel by automobile, and parks all too often become locales for crime rather than social intercourse"). Four years later, Justice Kennedy observed: "Minds are not changed in streets and parks as they once were. To an increasing degree, the more significant interchanges of ideas and shaping of public consciousness occur in mass and electronic media." Denver Area Educ. Telecomm. Consortium, Inc. v. FCC, 518 U.S. 727, 802-03 (1996) (Kennedy, J., concurring in part, concurring in the judgment in part, and dissenting in part).

14. See Mark Gottdiener, The Theming of America: Dreams, Visions, AND COMMERCIAL SPACES 139-42 (1997) (charting "the disappearance of public space" and its replacement by privately-owned environments in which we live out our daily lives); KUNSTLER, supra note 13, at 119-20 (recounting the dramatic shift from public to private space as the scene of daily life in America); Mike Davis, Fortress Los Angeles: The Militarization of Urban Space, in VARIATIONS ON A 
THEME PARK, supra note 12, at 154-155 (describing the "architectural privatization of the physical public sphere"). "[T]he marketplace had always been a public space," writes Kunstler, "part of the fabric of the town, usually at the heart of it, existing in continuity with the rest of town life." KUNSTLER, supra note 13, at 119 (alteration added). But "[b]y the 1970s, when malls started to multiply across the land, the public realm had pretty much been eliminated from the American scene." Id. (alteration added). "[T]he mall wasn't really a public space. It was a private space masquerading as a public space." Id. at 119-20 (alteration added). For Mark Gottdiener, the mall's preoccupation with profit-making poisons its capacity to serve as a public forum:

The mall may be the new space of public communion, as some have suggested, but it functions in that capacity only within the very restricted context of consumption .... Primed at home by mass media for self-realization through consumption, people enter the pseudo-public space of the themed environment without either political or social desires, as they may once have in earlier times. They pursue self-fulfillment in these places in the only way allowed, through the realization of the consumer role. This is a far cry from the multidimensional everyday urban life of the past.

GOTTDIENER, supra, at 142. As Mike Davis reports, the impulse to privatize and isolate our daily environment has even reached our urban downtowns:

The universal consequence of the crusade to secure the city is the destruction of any truly democratic urban space. The American city is being systematically turned inward. The "public" spaces of the new megastructures and supermalls have supplanted traditional streets and disciplined their spontaneity. Inside malls, office centers, and cultural complexes, public activities are sorted into strictly functional compartments under the gaze of private police forces.

Davis, supra, at 155.

15. See JACKSON, supra note 13 , at 260 (the central business districts of yesterday have been eclipsed by the mega-malls of today); Margaret Crawford, The World in a Shopping Mall, in VARIATIONS ON A THEME PARK, supra note 12, at 3, 611 (describing the science of mall design); Witold Rybczynski, The New Downtowns, THE ATLANTIC MONTHLY, May 1993, at 98 (surveying the history of shopping malls, tracing their development as "the new downtowns," and illustrating the growing obsolescence of traditional public forums). The New Jersey Supreme Court was keenly aware of this trend when it adopted an expansive interpretation of the speech clause in its state constitution, recognizing a limited right of expressive access to the common areas of privately-owned shopping malls: 
This problem is compounded by a second trend: governmental efforts to divest a public square, park, street, or sidewalk of its status as a

\begin{abstract}
Our constitutional right encompasses more than leafleting and associated speech on sidewalks located in empty downtown business districts. It means communicating with the people in the new commercial and social centers; if the people have left for the shopping centers, our constitutional right includes the right to go there too, to follow them, and to talk to them. We do not believe that those who adopted a constitutional provision granting a right of free speech wanted it to diminish in importance as society changed, to be dependent on the unrelated accidents of economic transformation, or to be silenced because of a new way of doing business.
\end{abstract}

N.J. Coal. Against War in the Middle East v. J.M.B. Realty Corp., 650 A.2d 757, 779 (N.J. 1994). See generally Jennifer A. Klear, Comparison of the Federal Courts' and the New Jersey Supreme Court's Treatments of Free Speech on Private Property: Where Won't We Have the Freedom to Speak Next?, 33 RUTGERS L.J. 589 (2002) (focusing on New Jersey's broad interpretation of the speech clause in its state constitution); Jennifer Niles Coffin, Note, The United Mall of America: Free Speech, State Constitutions, and the Growing Fortress of Private Property, 33 U. MICH. J.L. REFORM 615 (2000) (focusing on the largely unsuccessful national effort to persuade state courts to construe their state constitutions as affording some limited right of expressive access to the common areas of privately-owned shopping malls). See also generally Mark C. Alexander, Attention, Shoppers: The First Amendment in the Modern Shopping Mall, 41 ARIZ. L. REV. 1 (1999) (lamenting and critiquing the United States Supreme Court's refusal to extend federal free speech access to shopping malls, and proposing an alternative theory of First Amendment interpretation that would afford such access).

16. Lloyd Corp. v. Tanner, 407 U.S. 551, 567 (1972). See generally Jason K. Levine, Defending the Freedom to Be Heard: Where Alternate Avenues Intersect Empty Public Spaces, 36 U. MEM. L. REv. 277 (2006) (urging an expansive view of public space that focuses on how the property is actually used rather than who owns it, and relying upon the Supreme Court's alternative-channels-of-communication requirement as the basis for enlarging the range of spaces to which First Amendment protection extends); Josh Mulligan, Note, Finding a Forum in the Simulated City: Mega Malls, Gated Towns, and the Promise of Pruneyard, 13 CORNELL J.L. \& PUB. POL'Y 533 (2004) (exploring the demise of public space and the rise of private space as the scene of daily living in the United States and arguing that First Amendment jurisprudence must respond to this trend by adjusting its conception of the public forum). 
traditional public forum. ${ }^{17}$ This second trend has appeared in several different guises:

(a) The government tries to convert a traditional public forum into a non-public forum. In some cases, the government will attempt to relegate a traditional public forum to the status of a non-public forum. In United States v. Grace, ${ }^{18}$ for example, Congress enacted a statute that completely prohibited leafleting or displaying signs on the United States Supreme Court's sidewalk. The Court struck down the statute, holding that a traditional public forum cannot be transformed by government fiat into a non-public forum. ${ }^{19}$ Grace suggests that the government has no power to demote a given forum from traditional to non-public status. This conclusion is consistent with the Court's subsequent holding, in Frisby v. Schultz, ${ }^{20}$ that sidewalks do not lose their traditional public forum status when they reach the tree-lined enclaves of suburbia. ${ }^{21}$ United States $v$. Kokinda ${ }^{22}$ does not hold otherwise. In concluding that post office sidewalks do not constitute traditional public forums, ${ }^{23}$ Kokinda was not addressing a "demotion" scenario; the case did not involve an effort to relegate a forum from traditional to non-public status. Instead, Kokinda stressed that post office sidewalks had never attained traditional public forum status in the first place; that they did not function in the same way as "public" sidewalks in serving as a traditional bastion of public discourse. ${ }^{24}$ Thus, Kokinda does not contradict the holding in Grace that a traditional public forum cannot be transformed by government fiat into a non-public forum.

(b) When an event is staged within a traditional public forum, the government asserts that the event is a non-public forum. In some cases, an event or festival is staged on government property that is

17. I first identified this trend in a brief section of a long article that covered many different aspects of public protest law. See Kevin Francis O'Neill, Disentangling the Law of Public Protest, 45 LoY. L. REV. 411, 457-62 (1999).

18. 461 U.S. 171 (1983).

19. Id. at 180 . The Court concluded that so sweeping a prohibition could not be sustained under the standard that governs time, place, and manner restrictions on speech in traditional public forums. Id. at 180-81.

20. 487 U.S. 474 (1988).

21. See id. at $480-81$.

22. 497 U.S. 720 (1990).

23. Id. at 727 .

24. See id. 
indisputably a traditional public forum. Rather than arguing that the property is a non-public forum, the government contends that the event is a non-public forum. Though such an argument would seem to exemplify an all-too-clever sleight-of-hand, some courts have accepted it. In Community for Creative Non-Violence v. Hodel, ${ }^{25}$ for example, a public advocacy group was rebuffed by the National Park Service in its request to include a controversial statue-depicting a homeless man sleeping on a steam grate-in the Christmas Pageant of Peace, a "national celebration event" ${ }^{, 26}$ held annually on the Ellipse in Washington, D.C. The federal district court narrowly defined the "relevant forum" as the pageant (i.e., the event), not the Ellipse (i.e., the land on which the event was staged)-and concluded that, since the pageant was a non-public forum, the Park Service was free to select only "traditional" Christmas displays for inclusion in the event. ${ }^{27}$ Since the Ellipse is unquestionably a traditional public forum, identifying the pageant as the "relevant forum" enabled the court to conclude that a public forum had been converted into a non-public forum. The government made the very same argument in Irish Subcommittee of the Rhode Island Heritage Commission v. Rhode Island Heritage Commission, ${ }^{28}$ but encountered a very different reaction. The federal district court struck down, as content-based restrictions on public forum speech, a state commission's regulations prohibiting the display or distribution of any political paraphernalia -including political buttons, pins, hats, and pamphlets-at the Rhode Island Heritage Day festivities. The court rejected the argument that the festival as a whole (which was situated on the statehouse grounds) or its booths (from which the plaintiffs distributed their political paraphernalia) lacked the status of a traditional public forum. $^{29}$ And it emphatically refused to make the festival the relevant forum, as if it were a non-public-forum island in the traditional-publicforum sea of the statehouse grounds: "To allow the government to limit

25. 623 F. Supp. 528 (D.D.C. 1985).

26. Id. at 529 .

27. Id. at 533. The court went on to conclude that the plaintiffs' First Amendment rights would not be violated if they were permitted to erect their statue on the Ellipse but outside the pageant boundary. See id. at 535.

28. 646 F. Supp. 347 (D.R.I. 1986).

29. Id. at $352-53$. 
traditional public forum property and thereby create within it a nonpublic forum would destroy the entire concept of a public forum."

(c) The government allows or effects the physical transformation of a traditional public forum and then asserts that the property can no longer be regarded as a traditional public forum. In Hawkins v. City \& County of Denver, ${ }^{31}$ the Tenth Circuit concluded that a former public street-now converted to a 600 -foot-long, open-air, but glass-covered, pedestrian walkway affording ingress and egress to a government-owned performing arts complex - was now a non-public forum, notwithstanding what may have been its status as a traditional public forum before the transformation. $^{32}$ But two subsequent decisions have rejected this physical transformation thesis. In ACLU of Nevada v. City of Las Vegas, ${ }^{33}$ the Ninth Circuit held that the city's transformation of several blocks of downtown Las Vegas into a pedestrian mall did not destroy the area's status as a traditional public forum. ${ }^{34}$ And in Venetian Casino Resort v. Local Joint Executive Board of Las Vegas, ${ }^{35}$ another panel of the Ninth Circuit held that a sidewalk constructed on private property to replace a public sidewalk, accommodating pedestrian traffic adjacent to Las Vegas Boulevard, was a traditional public forum that retained the protections of the First Amendment. ${ }^{36}$

(d) The government sells a traditional public forum to a private entity, ${ }^{37}$ thereby converting the forum into private property. In perhaps

30. Id. at 354 n.3.

31. 170 F.3d 1281 (10th Cir. 1999).

32. Id. at 1287-88.

33. 333 F.3d 1092 (9th Cir. 2003), cert. denied, 540 U.S. 1110 (2004).

34. Id. at 1101-04.

35. 257 F.3d 937 (9th Cir. 2001), cert. denied, 535 U.S. 905 (2002).

36. Id. at 948. See Allen Lichtenstein \& Gary Peck, Sidewalk Democracy: Free Speech, Public Space and the Constitution, 8 NEV. LAW. 18 (2000) (describing the ACLU of Nevada's struggles in the Las Vegas sidewalk litigation and offering a useful summary of the public forum doctrine).

37. Some municipalities have tried to achieve the privatization of public streets and sidewalks through a measure that is less drastic than selling them to a private entity. To combat crime and drug-dealing in a public housing complex, the City of Richmond, Virginia deeded the surrounding streets and sidewalks to the Richmond Redevelopment and Housing Authority (RRHA), which owned and operated the complex. Virginia v. Hicks, 539 U.S. 113, 115-16 (2003). In pursuing this measure, the Richmond City Council consciously sought to "privatize" those streets and sidewalks, id. at 115 , thereby facilitating the use of a state trespass statute to 
the most heavy-handed example of a governmental entity taking steps to shut down a traditional public forum, Salt Lake City sold an entire block of Main Street to the Mormon Church. ${ }^{38}$ That section of Main Street, located near the Salt Lake Temple in the very center of downtown, had served since the 1840s as the site of so many protests and demonstrations that it was known as "Soapbox Corner."39 Now that it owned the property, the Mormon Church could ban assembling, demonstrating, and picketing there. ${ }^{40}$ But under the initial terms of the sale, the City retained a public easement for public access and passage-and, in the first of two challenges to the sale, the Tenth Circuit held that this easement constituted a traditional public forum. ${ }^{41}$ Following that decision, the City sold the easement to the Church, expressly eliminating any right of public access or passage. That proved decisive in the second challenge.

discourage undesirables from returning there. $I d$. at 116-17. The Council enacted an ordinance declaring that the streets in question "are hereby closed to public use and travel and abandoned as streets of the City of Richmond." Id. at 115-16. The deed required RRHA to create the appearance that the streets and sidewalks were no longer public, so it posted signs that declared: "YOU ARE NOW ENTERING PRIVATE PROPERTY AND STREETS OWNED BY RRHA. UNAUTHORIZED PERSONS WILL BE SUBJECT TO ARREST AND PROSECUTION." Id. at 116. But RRHA was itself a governmental entity, so the deeding of the streets and sidewalks did not actually result in their transfer to private ownership. Id. at 117118. In Hicks, the Supreme Court rejected a First Amendment overbreadth challenge to the trespass policy without expressly deciding whether the "privatized" streets and sidewalks should be analyzed as retaining their status as a traditional public forum. See The Supreme Court-Leading Cases, 117 HARV. L. REV. 226, 360 (2003). One commentator, expressing disappointment at the Court's failure to address this issue, asserted that "nominal street privatizations, like those at issue in Hicks, do not alter the constitutional calculus that normally applies to public streets and sidewalks." Id. at 369 . I emphatically agree-especially in a fact pattern like Hicks, where no gates or barricades to outside traffic were erected, where the streets and sidewalks were not physically altered in any way, and where they remained just as accessible to foot and vehicular traffic as before the transfer of ownership. See id. at 361 .

38. John Ritter, Mormons' Property Buy Challenged, USA TODAY, Nov. 23, 1999, at $3 \mathrm{~A}$ (describing the sale and the subsequent constitutional challenges brought by the ACLU).

39. Id.

40. Utah Gospel Mission v. Salt Lake City Corp., 425 F.3d 1249 (10th Cir. 2005).

41. First Unitarian Church of Salt Lake City v. Salt Lake City Corp., 308 F.3d 1114, 1131 (10th Cir. 2002). 
The Tenth Circuit held that because the Church was now the exclusive owner of the property, the street could no longer be regarded as any sort of public forum. It was beyond the reach of the First Amendment. Thus, the Church was free to ban speech there because it was not engaging in state action. ${ }^{42}$

(e) The government issues a permit by which a traditional public forum is temporarily turned over to a private actor who then enjoys the power to exclude citizens based on their viewpoints. During the last several election cycles, presidential campaigns have quietly pioneered a new method of privatizing traditional public forums in order to stifle dissent at outdoor rallies. In these scenarios, the campaign committee (a private actor) secures a permit from a municipality to use a traditional public forum (usually a public square) as the venue for a speech by the candidate. ${ }^{43}$ The committee then treats the forum as if it were private

42. Utah Gospel Mission, 425 F.3d at 1255.

43. See, e.g., Sistrunk v. City of Strongsville, 99 F.3d 194 (6th Cir. 1996) (holding that a municipality could lease its town commons, a traditional public forum, to the Bush-Quayle '92 Campaign for the purpose of holding a campaign rally, and that the organization could in turn make attendance at its rally conditioned upon surrendering any visible expression of support for the opposing candidate); $i d$. at 199-200 (rejecting First Amendment claims by high school student who was stripped of her "Clinton for President" button as a precondition for admission into the campaign rally); Bishop v. Reagan-Bush '84 Comm., No. 86-3287, 1987 WL 35970 (6th Cir. May 22, 1987) (reversing trial court's grant of summary judgment for defendants-Cincinnati police, Secret Service agents, and local and national members of the Reagan-Bush campaign committee-who had excluded plaintiff protesters from attending a campaign rally in Cincinnati's Fountain Square unless they surrendered all signs critical of the Reagan Administration); McCabe v. Basham, 450 F. Supp. 2d 916 (N.D. Iowa 2006) (dismissing two defendants-the Secret Service and Homeland Security directors-for lack of in personam jurisdiction, never reaching the First Amendment merits of a lawsuit alleging viewpoint-based expulsion from George $\mathrm{W}$. Bush re-election rally in public park); Schwitzgebel v. City of Strongsville, 898 F. Supp. 1208 (N.D. Ohio 1995), aff'd mem., 97 F.3d 1452 (6th Cir. 1996) (rejecting First Amendment claims by two AIDS activists who, while attending a campaign speech by President George Herbert Walker Bush in a traditional public forum, were ejected and arrested after silently unfurling a banner critical of Bush's policy on AIDS); id. at 1215-16 (flatly rejecting the contention that, in granting the Bush campaign a permit to conduct its rally on the Strongsville Commons-a traditional public forum-the town thereby converted the Commons into a non-public forum during the President's speech); id. at 1219 (but holding that government has the power to eject counter-demonstrators from 
property, excluding citizens who oppose the candidate and making attendance at the rally conditioned upon surrendering any visible expression of support for the candidate's rival. ${ }^{44}$ Whether a traditional public forum may be "privatized" in this way has divided the courts. Emblematic of the split are two cases that stem from the same campaign rally-Sistrunk v. City of Strongsville ${ }^{45}$ and Schwitzgebel v. City of Strongsville ${ }^{46}$-in which one court endorsed and the other rejected a "privatization" thesis.

(f) The government temporarily privatizes a traditional public forum by granting itself a permit to occupy the forum on a specific occasion. In Mahoney v. Babbitt, ${ }^{47}$ the National Park Service attempted to privatize certain sidewalks lining the route of President Clinton's inaugural parade, with a view toward thwarting anti-abortion protesters who sought to display banners there. As the D.C. Circuit described it, "the government granted itself a permit for the sidewalks from which it then sought to ban the 'inconsistent' First Amendment-protected activity" of the anti-abortion protesters. ${ }^{48}$ Siding with the protesters, the court flatly refused "[to] permit the government to destroy the [traditional] public forum character of the sidewalks along Pennsylvania Avenue by the ipse dixit act of declaring itself a permittee." emphatically concluded that "there is no authority for the proposition that the government may by fiat take a [traditional] public forum out of the protection of the First Amendment by behaving as if it were a private actor." 50 Mahoney appears distinguishable from Sistrunk and Schwitzgebel in one important respect: The latter cases involved private permittees, while Mahoney involved the government itself occupying a traditional public forum and excluding citizens based on the viewpoint of

even a traditional public forum if their expression impinges upon that of a speaker already ensconced there by means of a permit).

44. See Sistrunk, 99 F.3d at 196; Bishop, 1987 WL 35970 at *1; Schwitzgebel, 898 F. Supp. at 1212-13.

45. 99 F.3d 194 (6th Cir. 1996).

46. 898 F. Supp. 1208 (N.D. Ohio 1995), aff'd mem., 97 F.3d 1452 (6th Cir. 1996). I devote greater attention to these cases in the next section of this article.

47. 105 F.3d 1452 (D.C. Cir. 1997).

48. Id. at 1457.

49. Id. at 1458 (alterations added).

50. Id. at 1457 (alteration added). 
their intended expression. In this sense, Mahoney is the easier case; while the censorship in Sistrunk and Schwitzgebel was carried out by private actors with governmental acquiescence, the censorship in Mahoney was committed directly and affirmatively by the state. ${ }^{51}$

In the following section, I will focus on the Sistrunk/ Schwitzgebel line of cases identified in paragraph (e), with a view toward analyzing the particular First Amendment issues that arise when presidential campaigns seek to eliminate dissent at outdoor rallies by "privatizing" traditional public forums.

\section{The PRoblem: EFforts by PREsidential CAMPAIGNS To ERADICATE ANY TRACE OF DISSENT AT OUTDOOR RALLIES BY TEMPORARILY "Privatizing" TRADITIONAL PUBLIC FORUMS ${ }^{53}$}

We have all seen it on the evening news: the presidential campaign rally in an outdoor, downtown setting. Carefully packaged and smoothly choreographed, it is designed to accomplish one objective- to create the illusion of a candidate whom everyone loves, a juggernaut rolling to certain victory. The adoring crowd looks like a random collection of citizens from all walks of life and every political stripe. But nothing could be further from the truth. The audience has been rigorously cleansed of every potential dissenter. It has been hand-picked to contain only the most faithful supporters. ${ }^{54}$ This spectacle is not so

51. Lurking here--but so far avoided by the courts, see, e.g., Sistrunk v. City of Strongsville, 99 F.3d 194, 197 (6th Cir. 1996)-is the question of state action: Is the First Amendment even implicated when a private permittee ejects other speakers from a public forum? I discuss the state action issue in footnote 69 , infra.

52. In future articles, I will return to this general topic-governmental efforts to divest a public square, park, street, or sidewalk of its status as a traditional public forum - and take up one or more of the other categories set forth above.

53. This article focuses solely upon campaign rallies that are staged in traditional public forums-public squares and public parks. I am not addressing rallies that are staged on private property (e.g., a church or a hotel ballroom) or on public property that likely constitutes a non-public forum (e.g., the gymnasium of a public high school).

54. See Joshua Green, Company, Left, The Atlantic MonThly, Jan.-Feb. 2006 , at 40 (describing the "KGB-style interrogation" and ejection of potential dissenters that is "sadly characteristic of [George W.] Bush campaign events" 
much an actual campaign rally as a theatrical performance for the television cameras-even the audience members are actors playing a role.

Every election cycle brings a new spate of these rallies. Ronald Reagan pioneered them. ${ }^{55}$ George Herbert Walker Bush $^{56}$ and Bill Clinton $^{57}$ employed them. And George W. Bush has taken them to a new level-especially in the zeal of his staff to eradicate any hint of dissent. ${ }^{58}$ Typically, attendance at a Bush campaign rally is forbidden unless the attendee has somehow managed to secure a ticket. ${ }^{59}$ These tickets are

(alteration added)); Richard Benke (Associated Press), New Mexico GOP to Continue Asking for Pledge (Aug. 5, 2004), available at http://www.boston.com/ne' ws/politics/president/articles/2004/08/05/nm_gop_to_keep_screening_for_bush_eve nts?mode $=$ PF (the Republican Party of New Mexico screened audience members for Bush-Cheney campaign appearances by withholding admission until each attendee had signed a pledge supporting Bush's re-election as President); Kelly Beaucar Vlahos, Screening Tactics at Bush Events Questioned, Apr. 22, 2005, http://www.foxnews.com/story/0,2933,153720,00.html (describing the great lengths to which George W. Bush's staffers will go in screening and ejecting any person whose political views may not match the President's. Three audience members at a Denver appearance were forced to leave when the Secret Service found a bumper sticker on their car that read "No More Blood for Oil."); Bill Cook, Assistant City Attorney for Farmington, New Mexico, telephone interview with the author, Oct. 20, 2004 (confirming from first-hand experience that screeners for Bush campaign appearances in New Mexico had turned away all Democrats who wished to attend, even if they were not wearing buttons, carrying signs, or otherwise manifesting any support for a rival candidate).

55. See Bishop v. Reagan-Bush '84 Committee, No. 86-3287, 1987 WL 35970 (6th Cir. May 22, 1987) (reflecting efforts by the Reagan-Bush campaign to eliminate any signs from a public square rally that manifested support for a rival candidate).

56. See Sistrunk v. City of Strongsville, 99 F.3d 194 (6th Cir. 1996) (reflecting efforts by the Bush-Quayle campaign to eliminate from a public square rally any visual manifestation of criticism for the Bush Administration or support for any rival candidate); Schwitzgebel v. City of Strongsville, 898 F. Supp. 1208 (N.D. Ohio 1995), aff'd mem., 97 F.3d 1452 (6th Cir. 1996) (same).

57. See Rob Eure, Nader Supporters Upset at Ban on Signs at Clinton Rally Site, PORTLAND OREgONIAN (Sept. 25, 1996), available at 1996 WL 11387928 (describing efforts by the Clinton-Gore campaign to cleanse their public square rallies of any visual signs of support for a rival candidate); John Lazo, Jr., Dissent Isn't Part of the Political Package, Plain Dealer (Cleveland, OH), Oct. 29, 1996, at $10 \mathrm{~B}$ (same).

58. See supra note 54 and accompanying text.

59. Benke, supra note 54; Vlahos, supra note 54. 
usually issued by local officials of the Republican Party. ${ }^{60}$ To receive a ticket, it is often necessary to perform some volunteer work for the local Bush campaign or to fill out a questionnaire, disclosing your home address, your e-mail address, and your Social Security number. ${ }^{61}$ Finally, some Republican Party officials during the last election imposed yet another prerequisite: Applicants were denied a ticket unless they agreed to sign an endorsement pledge affirming their support for President Bush's re-election. ${ }^{62}$ In New Mexico, the official pledge was worded as follows: "I . . . herby [sic] endorse George W. Bush for reelection of [sic] the United States." ${ }^{, 63}$ One man who refused to take this pledge (and was therefore denied tickets) said that he had also been quizzed about his political views and affiliations. Specifically, he was asked whether he associated with pro-life, gun rights, veterans, or teacher organizations. ${ }^{64}$ Moreover, he was asked to disclose his driver's license number for a background check by the Secret Service. ${ }^{65}$ Even if the applicant survives all this scrutiny and manages to secure a ticket, he can still be ejected for harboring the "wrong" political viewpoint-no matter how minutely or invisibly that viewpoint is reflected on his clothing or possessions. At a Minnesota campaign rally, a high school student holding a ticket was ordered to leave when staffers discovered a John Kerry sticker on his wallet. ${ }^{66}$ One wonders just how visible that wallet sticker would have been to the television cameras. At a Denver event, three young adults had gained admission with tickets and were peacefully awaiting President Bush's arrival when they were forced to leave. They were neither carrying nor wearing any visible message suggesting antagonism toward the President. But Secret Service agents had traced them to a car that bore an anti-war bumper sticker--"No More Blood for Oil" ${ }^{, 67}$-and that was enough to trigger their ejection.

The success of these rallies depends on their ability to convey the illusion of unanimous support for the candidate. This means that

60. Benke, supra note 54.

61. Vlahos, supra note 54.

62. Benke, supra note 54.

63. Id.

64. Id.

65. Id.

66. Green, supra note 54.

67. Vlahos, supra note 54. 
when rallies are staged in a traditional public forum, citizens who would normally be free to attend must be carefully screened and excluded if they fail to possess the "correct" viewpoint. Under the First Amendment, viewpoint-based exclusions from a traditional public forum are unconstitutional if effectuated by the government. ${ }^{68}$ But here, of course, the screenings and exclusions are carried out by a private actor (the campaign committee), not by the government. ${ }^{69}$ That private actor enjoys temporary control over the forum thanks to a permit issued by the municipality. From a First Amendment perspective, what is the effect of the granting of the permit? Does it privatize a traditional public forum during the period in which the campaign rally occupies that forum? There are very few cases that address this question and they do not agree on the answer. (The paucity of case law is surprising given the high visibility of presidential campaigns and the howls of protest that frequently attend the viewpoint-based ejections of would-be spectators.) The leading cases are Sistrunk v. City of Strongsville ${ }^{70}$ and Schwitzgebel v. City of Strongsville. ${ }^{71}$ Let us take a closer look at them. ${ }^{72}$

68. See Capitol Square Review \& Advisory Bd. v. Pinette, 515 U.S. 753, 761 (1995); Boos v. Barry, 485 U.S. 312, 319 (1988).

69. This raises the question of state action: Is the First Amendment even implicated when a private actor ejects other speakers from a public forum? I think the answer here is yes-state action does exist and the First Amendment does apply-because the private actor owes its presence in the forum to a governmentissued permit. When a municipality grants one of these permits to a presidential campaign, the municipal officials know perfectly well that the campaign will utilize the permit to exclude any citizen who is not a loyal supporter of the candidate. See Vlahos, supra note 54; Benke, supra note 54. Thus, the government issues these permits with the knowledge that they will be used to impose viewpoint-based restrictions on access to a traditional public forum. This situation falls within the "entanglement" exception to the state action doctrine, which holds that state action exists when the government affirmatively facilitates private conduct that violates the Constitution. ERWIN ChemerinsKy, Constitutional LAW: PrINCIPLES AND POLICIES $\S 6.4 .4 .3$, at 527 ( $3 \mathrm{~d}$ ed. 2006). Since campaign officials are using their permit to regulate expressive access to government property, the situation falls just as readily into the other major exception to the state action doctrine-the "public functions" exception, which applies when traditional powers of government are exercised by a private entity. Id. at $\S 6.4 .4 .2$, at $518-19$.

70. 99 F.3d 194 (6th Cir. 1996).

71. 898 F. Supp. 1208 (N.D. Ohio 1995), aff'd mem., 97 F.3d 1452 (6th Cir. 1996). 
Sistrunk and Schwitzgebel both involve an October 28, 1992 campaign speech by George Herbert Walker Bush. The outdoor rally was staged in a traditional public forum, the Strongsville Commons, that Bush campaign officials purported to control by virtue of a one-dollar permit issued by the city. ${ }^{73}$ In both cases, the plaintiffs sought to engage in silent dissent-only to be censored in ways that would never be permissible in a traditional public forum. The Sistrunk plaintiff, a high school student, was stripped of her "Clinton for President" button as the price for access to the Commons. ${ }^{74}$ In Schwitzgebel, two men were ejected and arrested after silently unfurling a banner critical of Bush's policy on AIDS. ${ }^{75}$ Though both courts agreed that dissenters may be excluded from such a rally, ${ }^{76}$ they split on the "privatization" thesis, with Sistrunk endorsing. ${ }^{77}$ and Schwitzgebel rejecting ${ }^{78}$ it.

Sistrunk held that the First Amendment does not prevent a municipality from granting a permittee "exclusive use" of a traditional public forum. ${ }^{79}$ Unfortunately, the opinion is less than clear about its theoretical underpinnings. Left unanswered is whether the public nature of the forum is altered by the permit, or whether the "exclusive use" enjoyed by the permittee is simply a necessary concomitant of its expressive "autonomy." permittee is free to use a traditional public forum as if it were private property-engaging in viewpoint-based censorship that would be legally impermissible even in a non-public forum. ${ }^{81}$

Schwitzgebel, by contrast, expressly rejects the notion that a permit in any way alters the First Amendment status of a traditional

72. In laying out the background on Sistrunk and Schwitzgebel, my exposition borrows heavily from the article in which I first identified these cases. O'Neill, supra note 17 , at $460-61$.

73. Sistrunk, 99 F.3d at 196; Schwitzgebel, 898 F. Supp. at 1212.

74. Sistrunk, 99 F.3d at 196.

75. Schwitzgebel, 898 F. Supp. at 1212-13.

76. Sistrunk, 99 F.3d at 198-200; Schwitzgebel, 898 F. Supp. at 1216-19.

77. Sistrunk, 99 F.3d at 198.

78. Schwitzgebel, 898 F. Supp. at 1215-16.

79. Sistrunk, 99 F.3d at 198.

80. Id. at 200.

81. In a non-public forum, speech restrictions are analyzed under a reasonableness test, unless they are viewpoint-based. Perry Educ. Ass'n v. Perry Local Educators' Ass'n, 460 U.S. 37, 46 (1983). 
public forum. ${ }^{82}$ Concluding that the city's issuance of a permit to the Bush Campaign did not, even temporarily, relegate the Commons from traditional to non-public status, the court observed:

To allow the government to transform a traditionally public forum into a non-public forum is to allow the government to suspend, if only temporarily, the existence of an historically protected arena used to safeguard the communication of thoughts between free citizens. In essence, public [forums] serve as bulwarks protecting the right of all persons, especially those who have no access to any other outlet, to speak their minds freely. Courts must not allow the government to overcome the bastions protecting such an important right through so simple an exercise as the granting of a permit. ${ }^{83}$

Thus, held the court, a permittee's ejection of dissenting voices from a traditional public forum must be analyzed under the same First Amendment standards that normally apply to restrictions on public forum speech. ${ }^{84}$

Given the profoundly speech-protective language quoted above, it is ironic that the Schwitzgebel court arrived at a speech-restrictive conclusion-finding no First Amendment violation in ejecting, arresting, and jailing two citizens who peacefully and silently expressed their disagreement with the policies of a presidential candidate at an outdoor campaign speech in a traditional public forum. To achieve this result, the Schwitzgebel court performed a tortured time, place, and manner analysis-identifying a significant governmental interest in preventing the "cacophony", of conflicting messages (a curious choice of words, since the plaintiffs were holding their banner in silence), and concluding that the ejection of a rival viewpoint from a traditional public forum does not offend the content-neutrality requirement. ${ }^{86}$

82. Schwitzgebel, 898 F. Supp. at 1215-16.

83. Id. at 1216 (alteration added).

84. Id. at 1216-17.

85. Id. at $1217,1219$.

86. Id. at 1219. 
Thus, even though they disagree on the power of government to divest a space of its traditional public forum status, Sistrunk and Schwitzgebel arrive at the same result: When a speaker, by means of a permit, is ensconced in a traditional public forum, that forum is magically transformed into a "no dissent" zone. This strikes me as an unsatisfactory outcome, one that is difficult to square with the letter and the spirit of the public forum doctrine. If these cases are somehow correct-if a public forum permittee really is empowered to indulge in viewpoint-based exclusions of other citizens-I do not believe that either one of them employed the right analysis in reaching that conclusion. So in the next section of this article, I will attempt a First Amendment analysis of my own.

\section{ANALYSIS}

Let us begin by recognizing that the public forum doctrine governs expressive access only to government-owned property, ${ }^{87}$ while presidential campaigns remain entirely free to stage their rallies on private property. To the extent that these campaigns want to engage in viewpoint-based discrimination in selecting who may attend a rally, they risk offending the First Amendment by staging that rally in a traditional public forum. By contrast, they can discriminate to their hearts' content on private property, where there are no comparable limitations on their power to exclude. ${ }^{88}$ Why not simply rent out a hotel ballroom and restrict the guest list to those individuals who have submitted to a microscopic examination of their political loyalty? There is nothing in the First Amendment to forbid such a strategy. But a presidential speech in a hotel ballroom does not create the same impression on the television audience as the outdoor rally in a public square. And this is why the presidential campaigns will persist in the staging of public square rallies. Those rallies create the illusion of general popular support for the candidate-support that transcends party lines. The speech in the hotel

87. See Int'l Soc'y for Krishna Consciousness, Inc. v. Lee, 505 U.S. 672, 67879 (1992) (adopting the public forum doctrine to assess restrictions that the government seeks to place on expressive access to government property).

88. See Lloyd Corp., Ltd. v. Tanner, 407 U.S. 551, 567 (1972) (holding that speech restrictions imposed by private actors pertaining to private property are beyond the reach of the First Amendment.). 
ballroom is loaded with very different connotations. Its whole atmosphere evokes one-thousand-dollar-a-plate dinners, fat cats, and party insiders. Presidential campaigns will keep returning to traditional public forums because the televised image of a rally in such a forum is uniquely capable of suffusing a candidate with the aura of widespread support. But that aura will vanish if the candidate is heckled, booed, or confronted with hand-held signs that criticize him. Thus, traditional public forums are attractive to presidential campaigns only to the extent that they can be cleansed of dissent - only to the extent that they can be made to function like a movie studio's back lot.

Is Sistrunk correct that a municipality's grant of a permit effectively privatizes a traditional public forum? ${ }^{89}$ This view strikes me as untenable, given the lesson of United States $v$. Grace that a traditional public forum cannot be transformed by government fiat into a non-public forum. ${ }^{90}$ Recent cases-like $A C L U$ of Nevada v. City of Las Vegas ${ }^{91}$ and Venetian Casino Resort v. Local Joint Executive Board of Las Vegas ${ }^{92}$ hold that even the physical transformation of such a space does not alter its status as a traditional public forum. ${ }^{93}$ When coupled with Grace, these cases indicate that it is simply incorrect, as a matter of law and fact, to assert that the mere granting of a permit to use a traditional public forum somehow "privatizes" that forum, even temporarily. As a practical matter, the permittee does enjoy a superior right of access to that forum vis-à-vis other speakers. But it is highly questionable whether the permittee has any legal right to engage in the systematic, viewpointbased exclusion of audience members that is practiced by the presidential campaigns. After all, the forum remains public property, notwithstanding the permit. And it is not just any type of government-

89. Sistrunk v. City of Strongsville, 99 F.3d 194, 198 (6th Cir. 1996).

90. 461 U.S. 171,180 (1983).

91. 333 F.3d 1092 (9th Cir. 2003), cert. denied, 540 U.S. 1110 (2004).

92. 257 F.3d 937 (9th Cir. 2001), cert. denied, 535 U.S. 905 (2002).

93. See ACLU of Nevada, 333 F.3d at 1103 (holding that the transformation of a city street into a pedestrian mall by a private corporation did not alter its status as a public forum); Venetian Casino, 257 F.3d at 944-48 (holding that a casino's agreement with the city to relocate a public sidewalk onto casino property did not convert the sidewalk to a nonpublic forum). 
owned property. It is not a military arsenal..$^{94}$ It is not a nuclear weapons test site. ${ }^{95}$ It is not an elevator in a federal building. ${ }^{96}$ It is not a corridor in the Pentagon. ${ }^{97}$ In other words, it is not the type of governmentowned property to which protesters have long been excluded for the reason that it is incompatible with "unrestrained communication." are talking here about a public square-about a type of public property that, "by long tradition," has been set aside for "assembly and debate." 99 This public space, this traditional public forum, does not lose its public character through the mere issuance of a permit. It is not suddenly transformed into a country club or a corporate boardroom.

From a practical standpoint, the permittee is simply granted a temporary privilege to use that space as a platform for expression. But let us be clear about the purpose of that permit. It affords a platform to speak to the citizens who are there-to the citizenry at large. It is certainly not a license to close the forum-to treat it as the permittee's private preserve, like the outdoor equivalent of a hotel ballroom. Nothing in the public forum doctrine says that the speaker can import his own hand-picked audience-that the speaker somehow has the power to

94. See United States v. Quilty, 741 F.2d 1031, 1033 (7th Cir. 1984) (affirming federal trespass convictions of anti-nuclear protesters who staged an unauthorized demonstration at the Rock Island Arsenal and holding that a military arsenal is not a public forum); see also Greer v. Spock, 424 U.S. 828, 838 (1976) (holding that military bases are non-public forums and rejecting a challenge to a base regulation that banned all speeches and demonstrations of a partisan political nature).

95. See Hale v. Dep't of Energy, 806 F.2d 910, 917-18 (9th Cir. 1986) (rejecting First Amendment challenge by nuclear weapons protesters to Energy Department regulations governing demonstrations at the Nevada Nuclear Weapons Test Site).

96. See United States v. Sachs, 679 F.2d 1015, 1016, 1022 (1st Cir. 1982) (upholding conviction of anti-draft protester who sat down in federal building elevator and obstructed its use); see also United States v. Sroka, 307 F. Supp. 400, 402 (E.D. Wis. 1969) (rejecting First Amendment defense by anti-war protesters who assembled in a federal building corridor to read the names of soldiers killed in Vietnam and, upon the close of business, refused to leave the building).

97. See United States v. Shiel, 611 F.2d 526, 527-28 (4th Cir. 1979) (affirming defendant's conviction for lying down in a Pentagon corridor during a nuclear arms protest).

98. Paulsen v. County of Nassau, 925 F.2d 65, 69 (2d Cir. 1991) (describing the characteristics of a non-public forum).

99. Perry Educ. Ass'n v. Perry Local Educators' Ass'n, 460 U.S. 37, 45 (1983) (describing the characteristics of the traditional public forum). 
exclude the very citizens who happen to be downtown and want to hear what the speaker has to say. Why create a doctrine affording special speech access to certain heavily-traveled public spaces if the speaker is going to use that platform to communicate not with the public at large but with a privately-invited, hand-picked audience from whom the general public is rigorously segregated?

Expelling the general public from a public square and importing a privately-invited, hand-picked audience to populate a presidential campaign rally cannot be justified by analogizing the rally to a parade. A presidential campaign committee might be tempted to make this argument in light of the expressive autonomy that the Supreme Court conferred upon parade organizers in Hurley v. Irish-American Gay, Lesbian \& Bisexual Group of Boston, Inc. ${ }^{100}$ In Hurley, the Court held that Massachusetts could not invoke its public accommodations law to force the private organizers of a St. Patrick's Day parade to include a contingent of Irish gays and lesbians, whose very presence in the parade would impart a message that the organizers did not wish to convey. ${ }^{101}$ Compelling the inclusion of that group would effectively alter the expressive content of the organizers' parade, thereby violating the First Amendment as a species of compelled speech. ${ }^{102}$ The key holding in Hurley is that the "selection of contingents to make [up] a parade" is entitled to full First Amendment protection, no less than the editorial compilation of viewpoints on a newspaper's opinion pages. ${ }^{103}$ Armed with this holding, a presidential campaign might argue that its selection of audience members is akin to the selection of parade contingents in Hurley. But this analogy simply won't work. Hurley stressed that parades are inherently expressive, ${ }^{104}$ but the same cannot be said of the audience at a campaign rally. Audience members are basically reacting to the speaker at the podium, while parade contingents are far more affirmatively projecting their own particular viewpoints. At a campaign rally, the expressive content emanates from the candidate, not from the audience. At a parade, the expressive content emanates from the

100. 515 U.S. 557 (1995).

101. Id. at 579 .

102. Id. at 574-75.

103. Id. at 570 (alteration added) (citing Miami Herald Publishing Co. v. Tornillo, 418 U.S. 241, 258 (1974)).

104. Id. at 568-69. 
marchers, from the different contingents that file past us-and each contingent often expresses a highly individualized, if not unique, message. Meanwhile, the audience at a campaign rally merely echoes or endorses the viewpoints that emanate from the podium.

Thus, Schwitzgebel is certainly correct in holding that a permittee's ejection of dissenting voices from a traditional public forum must be analyzed under the same First Amendment standards that normally apply to restrictions on public forum speech. ${ }^{105}$ But Schwitzgebel leapt from that holding to a less credible conclusionnamely, that viewpoint-based discrimination by the campaign committee should be governed not by strict scrutiny but by the intermediate scrutiny normally reserved for content-neutral time, place, and manner restrictions. ${ }^{106}$ Under the normal application of the public forum doctrine, strict scrutiny would govern the type of viewpoint-based discrimination that the presidential campaigns employ. ${ }^{107}$ But even if we follow Schwitzgebel's lead and apply intermediate scrutiny, a constitutional violation seems just as likely-because intermediate scrutiny requires content neutrality, ${ }^{108}$ and the ideological screening practiced by the presidential campaigns is anything but content-neutral. In restricting access to the forum, their whole purpose is to prevent the expression of any rival viewpoint. They won't even permit the silent

105. Schwitzgebel v. City of Strongsville, 898 F. Supp. 1208, 1216-17 (N.D. Ohio 1995), aff'd mem., 97 F.3d 1452 (6th Cir. 1996). This holding is consistent with the requirements of the state action doctrine. My state action analysis appears in footnote 69 , supra.

106. Schwitzgebel, 898 F. Supp. at 1216-17.

107. See Capitol Square Review \& Advisory Bd. v. Pinette, 515 U.S. 753 (1995) (Governmental restrictions on the content-much less the viewpoint-of traditional public forum speech are presumptively unconstitutional; they will be struck down unless shown to be "necessary, and narrowly drawn, to serve a compelling state interest." Id. at 761.).

108. Traditional public forums can be regulated only via content-neutral time, place, and manner restrictions. To survive judicial scrutiny, such restrictions must be "justified without reference to the content of the regulated speech," "narrowly tailored to serve a significant governmental interest," and must "leave open ample alternative channels for communication of the information." Ward v. Rock Against Racism, 491 U.S. 781, 791 (1989) (quoting Clark v. Community for Creative NonViolence, 468 U.S. 288, 293 (1984)). 
presence of people who harbor an opposing viewpoint. ${ }^{109}$ This is not a content-neutral restriction.

What are we to make of Schwitzgebel's "cacophony" argument? ${ }^{110}$ It seems to impose a "one-viewpoint-at-a-time" approach to forum regulation. Once a permittee is safely ensconced in a traditional public forum, there can be no expression of rival or dissenting viewpoints. There is some support in the case law for the one-viewpointat-a-time approach. One finds it in Sanders v. United States, ${ }^{111}$ which rejected a First Amendment defense by a criminal defendant who was arrested for physically intruding upon the Pageant for Peace, an annual event held on the Ellipse, a traditional public forum in Washington, D.C. Hoping to publicize what he believed were three mysterious deaths in South Carolina, the defendant ventured without a permit onto the grounds of the Pageant and, after placing three small signs beneath the South Carolina Christmas tree, he stood beside the tree with a larger sign and remained there until being arrested. In language that Schwitzgebel quotes approvingly, the Sanders court stressed the "fundamental" interest "in guaranteeing citizens the right to participate in events or demonstrations of their own choosing without being subjected to interference by other citizens." 112 As if laying the groundwork for the one-viewpoint-at-a-time approach, the court stressed:

A physical intrusion into another event for the purpose of interjecting one's own convictions or beliefs is by definition an interference, regardless of how insubstantial or insignificant it might appear. As such, it is an interference with the rights of other citizens to enjoy the event or demonstration in which they have chosen to participate, and in an area reserved for them. ${ }^{113}$

But a host of authorities directly refute the one-viewpoint-at-atime approach as inconsistent with a longstanding First Amendment

109. See Green, supra note 54 at 40 ; Benke, supra note 54 , at 13 ; Vlahos, supra note 54.

110. Schwitzgebel, 898 F. Supp. at $1217,1219$. 1982).

111. 518 F. Supp. 728 (D.D.C. 1981), aff'd mem., 679 F.2d 262 (D.C. Cir.

112. Id. at 730 (quoted in Schwitzgebel, 898 F. Supp. at 1218).

113. Id. 
ideal: promoting the collision of competing viewpoints as the path to truth. ${ }^{1 / 4}$ Thus, courts have recognized First Amendment protection for counter-demonstration ${ }^{115}$ and even heckling. ${ }^{116}$

114. See, e.g., Terminiello v. City of Chicago, 337 U.S. 1, 4 (1949) (observing that "a function of free speech under our system of government is to invite dispute"); Abrams v. United States, 250 U.S. 616, 630 (1919) (Holmes, J., dissenting) (asserting that "the best test of truth is the power of the thought to get itself accepted in the competition of the market").

115. See City of Seven Hills v. Aryan Nations, 667 N.E.2d 942 (Ohio 1996) (rejecting a flat ban on counter-demonstrations and striking down an injunction that barred the simultaneous presence- on the residential street of accused Nazi war criminal John Demjanjuk-of demonstrators with opposing views on his readmission to the United States). In Seven Hills, the trial court had entered the injunction at the city's behest to prevent Holocaust survivors and the $\mathrm{Ku} \mathrm{Klux} \mathrm{Klan}$ from airing their diametrically opposing views at the same time in the same place. Id. at 945-946. See generally Kevin Francis O'Neill \& Raymond Vasvari, CounterDemonstration as Protected Speech: Finding the Right to Confrontation in Existing First Amendment Law, 23 HASTINGS CONST. L.Q. 77 (1995) (concluding that constitutional protection for counter-demonstration may be found in the extant cases and in the underlying purposes of the First Amendment).

116. See generally In re Kay, 464 P.2d 142 (Cal. 1970) (invoking the First Amendment to impose a narrowing construction upon California's disturbing-alawful-meeting statute, thereby overturning the convictions of farmworkers who heckled a congressman during a campaign speech in a public park). See City of Spokane v. McDonough, 485 P.2d 449 (Wash. 1971) (holding that a disorderly conduct ordinance could not constitutionally be enforced to punish an attendee at an outdoor rally who shouted "warmonger" at Vice Presidential candidate Spiro T. Agnew and, flashing the peace sign at him, yelled: "What the hell do you think this means?"). To the extent that courts are willing to recognize any First Amendment protection for heckling, their willingness will very much depend on where the heckling occurred. If it took place in a traditional public forum (as it did in the foregoing cases, Kay and Spokane), then the heckler may very well enjoy First Amendment protection. But if the heckling took place in a non-public forum, the heckler is likely bereft of protection. See, e.g., Iowa v. Hardin, 498 N.W.2d 677, 679-81 (Iowa 1993) (upholding disorderly conduct conviction of a heckler who intentionally disrupted a speech by President George Herbert Walker Bush during a Republican fundraising rally). The Iowa Supreme Court distinguished Kay from the facts in Hardin, where the defendant's disruptive conduct occurred in an auditorium filled with persons who had paid for the opportunity to hear the President's speech, the disruption effectively halted the program, and the defendant was removed and arrested only after twice being asked to cease his heckling. Id. at 681. See generally Eve H. Lewin Wagner, Note, Heckling: A Protected Right or Disorderly Conduct?, 60 S. CAL. L. REV. 215 (1986) (collecting cases and proposing an analytical standard). 
In City of Seven Hills $v$. Aryan Nations, ${ }^{117}$ the Ohio Supreme Court rejected a flat ban on counter-demonstrations-in a direct rebuke to the one-viewpoint-at-a-time approach to forum regulation. Specifically, the court struck down an injunction that barred the simultaneous presence - on the residential street of accused Nazi war criminal John Demjanjuk —of demonstrators with opposing viewpoints on his readmission to the United States. ${ }^{118}$ The trial court had entered the injunction at the city's behest to prevent Holocaust survivors and the $\mathrm{Ku}$ Klux Klan from airing their diametrically opposing views at the same time in the same place. ${ }^{119}$ Ultimately, the court concluded that the record offered insufficient proof of imminent or even likely violence, so that the counter-demonstration ban offended the First Amendment. ${ }^{120}$

Stressing "[t]he happy cacophony of democracy," directly repudiates Schwitzgebel's sense that cacophony in a traditional public forum must be avoided at all costs. ${ }^{122}$ Kay directly addresses the First Amendment right to heckle an elected representative in a traditional public forum-which would seem to be precisely the evil that presidential campaigns seek to avoid in their manipulation of public forum permits. Kay invoked the First Amendment to impose a narrowing construction upon California's disturbing-a-lawful-meeting statute, thereby overturning the convictions of farmworkers who

117. 667 N.E.2d 942 (Ohio 1996).

118. Id. at 946.

119. Id. at $946-47$.

120. Id. at $947-48$.

121. In re Kay, 464 P.2d 142, 148 (Cal. 1970) (en banc) (alteration added) (quoting Landry v. Daley, 280 F. Supp. 968, 970 (N.D. Ill. 1968)). Writing for the Court in Cohen v. California, Justice Harlan spoke in praise of cacophony:

To many, the immediate consequence of [our robust expressive] freedom may often appear to be only verbal tumult, discord, and even offensive utterance. These are, however, within established limits, in truth necessary side effects of the broader enduring values which the process of open debate permits us to achieve. That the air may at times seem filled with verbal cacophony is, in this sense, not a sign of weakness but of strength.

403 U.S. 15, 24-25 (1971) (alteration added).

122. Schwitzgebel v. City of Strongsville, 898 F. Supp. 1208, 1217, 1219 (N.D. Ohio 1995), aff'd mem., 97 F.3d 1452 (6th Cir. 1996). 
registered their disapproval of a congressman's labor policy by engaging in rhythmic clapping and shouting for five to ten minutes during his campaign speech in a city park. ${ }^{123}$ The court observed:

[Judicially-recognized limits on free expression do] not mean ... that the state can grant to the police a "roving commission" to enforce Robert's Rules of Order, since other First Amendment interests are likewise at stake. Audience activities, such as heckling, interrupting, harsh questioning, and booing, even though they may be impolite and discourteous, can nonetheless advance the goals of the First Amendment .... An unfavorable reception, such as that given Congressman Tunney in the instant case, represents one important method by which an officeholder's constituents can register disapproval of his conduct and seek redress of grievances. The First Amendment contemplates a debate of important public issues; its protection can hardly be narrowed to the meeting at which the audience must passively listen to a single point of view. The First Amendment does not merely insure a marketplace of ideas in which there is but one seller. ${ }^{124}$

In the end, the one-viewpoint-at-a-time approach to forum regulation reflects a fundamental misunderstanding of First Amendment jurisprudence. It attempts to impose a prissy insistence that a public forum speaker must never be ruffled by disagreement, must never be unsettled by the specter of dissent. This view is utterly foreign to the Supreme Court's longstanding recognition that public forum speech frequently entails the clash of competing viewpoints. The Court has stressed that "a function of free speech under our system of government is to invite dispute"-that it "may indeed best serve its high purpose when it induces a condition of unrest, creates dissatisfaction with

123. Kay, 464 P.2d at 145 .

124. Id. at 147 (citations omitted) (alteration added). 
conditions as they are, or even stirs people to anger." process of open debate" may often produce "verbal tumult," "cacophony," and "discord," these are the "necessary side effects" of our commitment to the free exchange of ideas. ${ }^{126}$ It is "a profound national commitment to the principle that debate on public issues should be uninhibited, robust, and wide-open" the speaker some latitude to employ "exaggeration," "vilification," and "false statement" in attacking public officials. ${ }^{128}$ Thus, when a speaker ventures into a public forum, he should expect a raucous, rough-andtumble atmosphere, where the audience need not sit in reverent silence. ${ }^{129}$ If his ideas meet with disapproval, observed Justice Douglas,

125. Terminiello v. City of Chicago, 337 U.S. 1,4 (1949) (reversing breachof-the-peace conviction of a widely vilified speaker whose anti-Semitic and racially inflammatory speech produced a near riot).

126. Cohen v. California, 403 U.S. 15, 24-25 (1971) (holding that the First Amendment precluded defendant's breach-of-the-peace conviction for walking through a courthouse corridor wearing a jacket bearing the words "Fuck the Draft").

127. New York Times Co. v. Sullivan, 376 U.S. 254, 270 (1964) (establishing a qualified protection under the First Amendment for defamatory falsehoods uttered by critics of official conduct).

128. Cantwell v. Connecticut, 310 U.S. 296, 310 (1940) (setting aside a breach-of-the-peace conviction of a Jehovah's Witness, who, in the course of his sidewalk proselytizing, incensed passers-by in playing a phonograph record that expressed virulently anti-Catholic sentiments).

129. See, e.g., In re Kay, 464 P.2d 142, 147 (Cal. 1970); Dempsey v. People, 117 P.3d 800, 808 (Colo. 2005); City of Spokane v. McDonough, 485 P.2d 449, 450 (Wash. 1971). Moreover, a public forum speaker cannot be denied a permit based on the likelihood that he will be confronted by a hostile audience. See, e.g., Collin v. Chicago Park Dist., 460 F.2d 746, 755 (7th Cir. 1972) (holding that Nazis were entitled to injunctive relief after city officials denied their application for a permit to hold a demonstration in a public park); $i d$. at 754-55 ("As to the possibility of there being hostile audience members causing violence, the law is quite clear that such considerations are impermissible in determining whether to grant permits .... [I]t is impermissible even to consider the threat of a hostile audience when ruling on a permit application or a request for injunction against a demonstration.") (citations omitted) (alteration added); Williams v. Wallace, 240 F. Supp. 100, 109 (M.D. Ala. 1965) (granting injunctive relief to Martin Luther King, Jr. and his fellow civil rights activists, ordering the State of Alabama to permit and not interfere with plaintiffs' planned march from Selma to Montgomery); id. at 109 ("The [State's] contention that there is some hostility to this march will not justify its denial. Nor will the threat of violence constitute an excuse for its denial.") (alteration added) (internal citation omitted); Village of Skokie v. Nat'l Socialist Party of Am., 366 N.E.2d 347, 
"there will commonly be mutterings and unrest and heckling from the crowd." "130 "It is neither unusual nor unexpected," wrote Justice Black, "that some people at public street meetings mutter, mill about, push, shove, or disagree, even violently, with the speaker. Indeed, it is rare where controversial topics are discussed that an outdoor crowd does not do some or all of these things." ${ }^{\text {"131 }}$ Audience members can be arrested, of

353 (Ill. App. Ct. 1977) (declining to enjoin a group of Nazis from marching through an Illinois suburb populated by hundreds of Holocaust survivors); id. at 353 (even though the government put on evidence showing that "if the defendants ever appear in Skokie to demonstrate, there... is a virtual certainty that thousands of irate Jewish citizens [will] physically attack [them]," court holds that the possible presence of a hostile and violent audience is an impermissible consideration in granting an injunction or withholding a permit) (alteration added); aff'd in part, rev'd in part, 373 N.E.2d 21 (Ill. 1978) (holding that appellate panel correctly refused to enjoin the Nazi march but erred in barring the Nazis from wearing their uniforms).

130. Feiner v. New York, 340 U.S. 315, 331 (Douglas, J., dissenting). Feiner upheld the disorderly conduct conviction of a college student who, standing atop a soapbox and using a loudspeaker, delivered a street-corner harangue to a crowd of eighty people in which his derogatory remarks about President Truman, the American Legion, the Mayor of Syracuse, and other local officials inspired a hostile audience reaction. Id. at 316-18. Voting 6-3, the Court held that the conviction could be sustained based on the trial court's findings that defendant encouraged his audience to become racially divided into hostile camps, that the gathering crowd was interfering with traffic, and that defendant repeatedly refused police requests to cease talking. Id. at 319-21. The continued vitality of Feiner remains in doubt, given the Civil Rights Trilogy of the 1960s: Edwards v. South Carolina, 372 U.S. 229 (1963) (setting aside breach-of-the-peace convictions of 187 civil rights protesters who, after marching peacefully on a sidewalk around the South Carolina State House grounds, refused a police order to disperse and, after 15 minutes of singing and speechmaking, were arrested); Cox v. Louisiana, 379 U.S. 536 (1965) (setting aside breach-of-the-peace conviction of a civil rights activist who led a peaceful march by 2000 students to a courthouse where, with songs, prayers, and speeches, they protested the arrest and incarceration of fellow activists who were being held in the adjacent jail-the demonstration ended in chaos when police fired tear gas at the students after defendant refused a dispersal order, which was prompted by muttering and grumbling among 100 to 300 white onlookers positioned across the street); Gregory v. City of Chicago, 394 U.S. 111 (1969) (overturning the disorderly conduct convictions of 85 civil rights protesters whose march to and picketing before the mayor's residence produced a hostile reaction by 1000 onlookers-Court held that First Amendment barred the protesters' convictions where, pelted by rocks and eggs, they remained peaceful throughout their demonstration and were arrested only after refusing a police dispersal demand prompted solely by the onlookers' unruliness).

131. Feiner, 340 U.S. at 325-26 (Black, J., dissenting). 
course, if they physically attack the speaker, ${ }^{132}$ but in a public forum they are certainly free to register their dissent by booing or jeering. ${ }^{133}$ If the speaker does not want to risk being booed or jeered, he is always free to deliver his speech in a private forum, like a hotel ballroom.

From a practical standpoint, the purpose of a public forum permit is not to authorize the physical capture of the forum, as if it were some medieval castle from which the Saracens must be expelled. The permit is merely a method for ensuring the reasonable sharing of the forum by multiple speakers. If, for example, a permittee wishes to use sound amplification equipment for her speech, then the permit system can be used to require that other speakers who also wish to use sound amplification equipment must reserve the forum for a different date or time. ${ }^{134}$ But a public forum permit is not a license to close the forum, or to exclude citizens who merely wish to listen rather than speak. And it is certainly not a license to import a hand-picked audience that displaces the public audience. A principal purpose of the public forum doctrine was to grant expressive access to certain heavily-traveled public spaces-spaces that were desirable as a platform for speech because they received a heavy concentration of pedestrian traffic. ${ }^{135}$ This was the

132. Sabel v. Stynchcombe, 746 F.2d 728, 731 (11th Cir. 1984) (overturning refusal-to-disperse convictions of Revolutionary Communist Party demonstrators who, in the course of a May Day rally, inspired a hostile reaction by 200 onlookers); id. at $731 \& \mathrm{n} .7$ (recognizing that police have a duty to protect unpopular speakers confronted by a hostile crowd, even to the point of arresting crowd members who physically threaten the speakers); Glasson v. City of Louisville, 518 F.2d 899, 912 (6th Cir. 1975) (sustaining $\S 1983$ action by a solitary anti-Nixon protester whose sign was destroyed by police at the behest of hostile onlookers); id. at 905-06 (holding that police not only violated the First Amendment by destroying plaintiff's sign but had an affirmative duty to protect her from the hostile crowd).

133. In re Kay, 464 P.2d at 147; Dempsey, 117 P.3d at $808 ;$ McDonough, 485 P.2d at 450 .

134. See, e.g., Stokes v. City of Madison, 930 F.2d 1163, 1172-73 (7th Cir. 1991) (upholding sound amplification ordinance regulating expressive access to a traditional public forum in Madison, Wisconsin).

135. The Supreme Court has frequently identified Hague v. CIO, 307 U.S. 496 (1939) as the inspiration for the public forum doctrine. See, e.g., Int'l Soc'y for Krishna Consciousness, Inc. v. Lee, 505 U.S. 672, 679 (1992) (invoking Hague); Members of City Council v. Taxpayers for Vincent, 466 U.S. 789, 813-14 (1984) (invoking Hague); Perry Educ. Ass'n v. Perry Local Educators' Ass'n, 460 U.S. 37, 45 (1983) (invoking Hague). In his enormously influential plurality opinion in 
characteristic that each of the "traditional" public forums shared. When the doctrine was first created, public squares, parks, and sidewalks all afforded the speaker a platform for reaching a concentrated mass of fellow citizens. ${ }^{136}$ Each of those locations afforded the speaker a built-in

Hague, Justice Roberts found a constitutional right to use "streets and parks for communication of views," Hague, 307 U.S. at 515-16, basing that right on the fact that "streets and parks . . . have immemorially been held in trust for the use of the public and, time out of mind, have been used for purposes of assembly, communicating thoughts between citizens, and discussing public questions." Id. at 515. That Justice Roberts was trying to protect the ability of speakers (even controversial speakers) to reach a broad public audience is revealed by Hague's factual context. Hague was a civil lawsuit that challenged the speech-restrictive policies of Frank "Boss" Hague, the mayor of Jersey City, New Jersey. SAMUEL WALKER, IN DEFENSE OF AMERICAN LIBERTIES 110 (1990). Mayor Hague was openly hostile to organized labor and the political left. He tried to suppress the Communists, the Socialists, the ACLU, and all labor unions, in particular the militant new Congress of Industrial Organizations ("CIO"). Id. To silence these groups, he banned them from public spaces-cutting off their communication with the citizenry. His tactics included: (1) the arbitrary denial of permits to hold public meetings, assemblies, and demonstrations; (2) police harassment of union picketers; (3) banning $\mathrm{CIO}$ and union leaflets; (4) padlocking a synagogue after a union meeting had been held there; and (5) evicting union organizers from Jersey City by giving them one-way train and ferry tickets out of town. Id. As plaintiffs in the Hague lawsuit, the targeted groups requested injunctive relief against these tactics. The Supreme Court complied, striking down ordinances that, inter alia, imposed a flat ban on the distribution of printed materials, and required a permit-issued at the unfettered discretion of the public safety director-for all public meetings and demonstrations. Hague, 307 U.S. at 516-18. By vindicating the rights of the targeted groups to engage in public meetings, demonstrations, leafleting, and picketing, Hague confirmed the important role played by public spaces in affording expressive access to the citizenry.

136. See Gey, supra note 9, at 1538-39 (public forum doctrine was designed to afford speakers access to other citizens for presenting and discussing political ideas); Harry Kalven, Jr., The Concept of the Public Forum: Cox v. Louisiana, 1965 SuP. CT. REV. 1, 11 (when speakers engage in "mass protest in public places," the "essential feature is [an] appeal to public opinion") (alteration added); Robert C. Post, Between Governance and Management: The History and Theory of the Public Forum, 34 UCLA L. REV. 1713, 1719 (1987) (early conceptions of the public forum doctrine regarded streets and parks as constitutionally important "because they were peculiarly fitted to foster" speech on public issues); Jamin B. Raskin \& Clark L. LeBlanc, Disfavored Speech about Favored Rights: Hill v. Colorado, the Vanishing Public Forum, and the Need for an Objective Speech Discrimination Test, 51 AM. U. L. REV. 179, 184-86 (2001) (public forum doctrine enables a speaker to disseminate his message to an audience of fellow citizens); Noah D. Zatz, Note, Sidewalks in 
audience. Thus, the idea of importing an audience-of a speaker bringing his own audience to displace the public-is a non sequitur in terms of the public forum doctrine. This is the primary legal flaw in what the presidential campaigns are doing. They are twisting the public forum doctrine to achieve a result that is unintelligible and antithetical to that doctrine. And this is why the televised image they hope to achieve is so misleading. When we see a presidential candidate speaking to a large crowd in a public square, our natural and subliminal assumption is that the crowd is a public audience, not a privately invited, hand-picked audience. It never enters our minds that the general public has been expelled from the forum-because we have always equated a public square with public access. This same assumption rests at the very core of the public forum doctrine.

\section{CONCLUSION}

This article is an effort to analyze a First Amendment issue of great importance that has somehow escaped the attention of scholars, judges, and lawyers. The lack of attention it has received is all the more

Cyberspace: Making Space for Public Forums in the Electronic Environment, 12 HARV. J.L. \& TECH. 149, 152, 161 (1998) (public forum doctrine was designed to afford communicative access to audiences-public forums are locations that are frequented by the public, locations where a speaker can reach a public audience). See also Schneider v. New Jersey, 308 U.S. 147 (1939) (striking down ordinances that prohibited leafleting without a license and gave municipal officials unfettered discretion to grant or deny such a license); id. at 163 (due to their public character, "streets are natural and proper places for the dissemination of information and opinion"). Stressing that the public forum doctrine is derived as much from the Assembly Clause as from the Speech Clause, Justice Kennedy has observed:

Public places are of necessity the locus for discussion of public issues, as well as protest against arbitrary government action. At the heart of our jurisprudence lies the principle that in a free nation citizens must have the right to gather and speak with other persons in public places. The recognition that certain government-owned property is a public forum provides open notice to citizens that their freedoms may be exercised there without fear of a censorial government, adding tangible reinforcement to the idea that we are a free people.

Lee, 505 U.S. at 696 (Kennedy, J., concurring) (emphasis added). 
puzzling given its prominent use by presidential election campaigns, which receive more publicity than any other aspect of American political life. Through the simple expedient of a permit, these campaigns have managed to "privatize" public squares, excluding citizens in a viewpointdiscriminatory manner that would be patently unconstitutional if carried out by the government. But since the government issues the very permit that purportedly authorizes such viewpoint discrimination, there is a genuine question as to whether the First Amendment can be so easily evaded. In offering my own analysis here, I have tried to remain true to the letter and the spirit of the public forum doctrine. It is my hope that this article will encourage lawyers, journalists, and scholars to look more carefully at the way that presidential campaigns have been manipulating traditional public forums. And it is my hope that this article will prove useful to any judges who are called on to confront this issue in a court of law. 